\title{
PENGARUH PROGRAM INDEKS PEMBANGUNAN MANUSIA (IPM) TERHADAP PENGENTASAN KEMISKINAN DI KECAMATAN BULELENG TAHUN 2011-2014
}

\author{
Ni Komang Meriyanti \\ Jurusan Pendidikan Ekonomi, Fakultas Ekonomi dan Bisnis \\ Universitas Pendidikan Ganesha \\ Singaraja, Indonesia \\ e-mail: mery weasley@yahoo.co.id
}

\begin{abstract}
ABSTRAK
Penelitian ini bertujuan untuk mengetahui (1) program Indeks Pembangunan Manusia (IPM) di Kecamatan Buleleng, Kabupaten Buleleng tahun 2011-2014, (2) pengentasan kemiskinan di Kecamatan Buleleng, Kabupaten Buleleng tahun 2011-2014 dan (3) pengaruh program IPM terhadap pengentasan kemiskinan di Kecamatan Buleleng, Kabupaten Buleleng tahun 2011-2014. Penelitian ini merupakan jenis penelitian kausalitatif. Teknik penentuan sampel yang digunakan adalah formulasi yang dikembangkan Slavin diperoleh 84 responden dari 515 populasi. Data dikumpulkan dengan mengunakan metode dokumentasi, wawancara dan kuesioner. Teknik analisis yang digunakan adalah analisis deskriftif kuantitatif dan korelasi product moment. Berdasarkan hasil penelitian menunjukkan bahwa program IPM berada pada kategori sangat baik sedangkan pengentasan kemiskinan berada pada kategori baik. Koefisien korelasi yang diperoleh sebesar 0,594 memiliki pengaruh positif dan signifikan. Hal ini menunjukkan keeratan hubungan antara program IPM terhadap pengentasan kemiskinan tergolong sedang. Sumbangan program IPM terhadap pengentasan kemiskinan sebesar 35,2\% sedangkan sisanya sebesar $64,8 \%$ dipengaruhi oleh faktor lain yang tidak diteliti.
\end{abstract}

Kata kunci: pengentasan kemiskinan, program IPM

\begin{abstract}
This research is aimed to know (1) Human Development Indeks (HDI) program in Buleleng District, Buleleng Regency in 2011-2014, (2) Poverty reduction in Buleleng District, Buleleng Regency in 20112014 and (3) the effect of HDI program towards poverty reduction in Buleleng District, Buleleng Regency in 2011-2014. This research was causalitative research. Sampling technique which is used in this research is formula which is developed by Slavin which is got 84 respondents from 515 population. Data collected by documentation method, interview, and questionnaire. Analysis technique which is used are descriptive quantitative and product moment correlation. The result of the research showed that IPM program in a very good category while poverty reduction in a good category. Correlation coefficient which is got is 0,594 had positive and significant effect. It showed the relationship strength level between IPM program towards poverty reduction was in a medium category. The contribution of IPM program towards poverty reduction was $35,2 \%$ while the rest was $64,8 \%$ influenced by other factors which are not researched.
\end{abstract}

Keywords: poverty reduction, HDI program

\section{PENDAHULUAN}

Kemiskinan merupakan fenomena yang kompleks, bersifat multidimensi dan tidak dapat secara mudah dilihat dari suatu angka absolut. "Salah satu faktor yang menyebabkan ketertinggalan dan penghambat dalam pembangunan suatu negara dalah tingginya angka kemiskinan" (Kuncoro,2005). Kemiskinan sendiri akan menimbulkan dampak yang bersifat menyebar (multiplier effects) terhadap aspek-aspek yang ada di masyarakat secara menyeluruh. Kemiskinan juga merupakan muara dari masalah sosial lainnya yang ada di lingkungan masyarakat.

Keberadaan penduduk miskin dalam suatu wilayah tidak akan 
membawa kemakmuran bagi wilayah tersebut sehingga wajib diberantas. Smith (dalam Todaro,2004:219) menyatakan bahwa "tidak ada masyarakat yang makmur dan bahagia, jika sebagian besar penduduknya berada dalam kemiskinan dan kesengsaraan". Oleh karena itu, pemberantasan kemiskinan telah menjadi tantangan utama dalam pembangunan, karena pembangunan ekonomi bukan terletak pada pendapatan yang dihasilkan suatu wilayah, tetapi pada peningkatan kualitas kehidupan penduduk.

$$
\text { Subandi (2012) menyatakan }
$$
salah satu strategi/upaya pengentasan kemiskinan adalah pembangunan Sumber Daya Manusia (SDM). Pembangunan SDM dapat dilakukan dengan perbaikan akses terhadap konsumsi pelayanan sosial (pendidikan, kesehatan dan gizi) merupakan strategi pemerintah untuk mengurangi kemiskinan dan meningkatkan kesejahteraan. Pembangunan manusia dapat diukur dengan Indeks Pembangunan Manusia (IPM) atau Human Development Index (HDI) yang merupakan suatu indeks komposit untuk mengukur pencapaian kualitas pembangunan manusia. Todaro (2006) menyatakan bahwa IPM menggambarkan indeks pengembangan manusia yang dilihat dari sisi perluasan, pemerataan, dan keadilan baik dalam bidang kesehatan, pendidikan, maupun kesejahteraan masyarakat. Rendahnya IPM akan mengakibatkan pada rendahnya produktivitas kerja dari penduduk. Produktivitas yang rendah mengakibatkan rendahnya perolehan pendapatan, sehingga menyebabkan tingginya jumlah penduduk miskin. Dalam hal ini, pembangunan manusia diukur dengan Indeks Pembangunan Manusia (IPM) atau Human Development Index (HDI) yang merupakan suatu indeks komposit untuk mengukur pencapaian kualitas pembangunan manusia.

Dalam rangka meningkatkan IPM, maka dirancanglah suatu program yang khusus yakni Program Keluarga Harapan (PKH). PKH adalah "suatu program dengan tersentuhnya rumah tangga sangat miskin dari program kesehatan dan pendidikan bagi anak balita, ibu hamil dan usia pendidikan dalam rangka meningkatkan indeks pembangunan manusia yang akan mempengaruhi jumlah penduduk miskin" (Satuan Kerja Perangkat Daerah,2013:4).

Bali memiliki permasalahan kemiskinan yang masih menjadi pokok permasalah yang harus mendapatkan perhatian ekstra. Salah satu kabupaten di Bali yang memiliki jumlah penduduk miskin adalah Kabupaten Buleleng. Kabupaten Buleleng memiliki masalah kemiskinan dan kesejahteraan penduduk yang masih harus mendapat perhatian serius. Pembangunan yang tidak merata di Provinsi Bali, menyebabkan Kabupaten Buleleng jarang mendapat sentuhan perhatian dari pemerintah pusat (Katalog BPS 2012:78). Menurut data PPLS 2011, lebih dari $11 \%$ penduduk miskin Kabupaten Buleleng berada di Kecamatan Buleleng.

Kecamatan Buleleng masih menghadapi masalah kemiskinan dan yang rentan untuk jatuh di bawah garis kemiskinan. Berdasarkan data PPLS Provinsi Bali (2011), penduduk miskin yang ada di Kecamatan Buleleng berjumlah 635 KK katerogi P1 2.168 KK kategori P2 dan $2.625 \mathrm{KK}$ kategori P3 yang tersebar di 29 desa/kelurahan. Kemiskinan yang terjadi di Kecamatan Buleleng membutuhkan penanganan yang tepat karena melihat dari kondisi geografis Kecamatan Buleleng ini terletak di wilayah perkotaan.

Menyadari masalah kemiskinan yang terjadi, maka $\mathrm{PKH}$ digulirkan pemerintah pusat untuk merespon permasalahan kemiskinan yang ada, seperti yang terdapat di Kecamatan Buleleng. Kecamatan Buleleng merupakan kecamatan yang paling banyak mendapat dana dari pemerintah. Data penduduk miskin peserta PKH di Kecamatan Buleleng dari tahun 2011-2014 cenderung 
memperlihatkan trend penurunan. Pada tahun 2011 sebanyak 574 Keluarga Sangat Miskin (KSM), tahun 2012 sebanyak 553 KSM, tahun 2013 sebanyak 532 KSM sedangkan pada tahun 2014 menjadi 515 KSM. Dengan adanya $\mathrm{PKH}$, diharapkan dapat memberikan kesempatan kepada masyarakat miskin yang ada di Kecamatan Buleleng untuk ikut berperan serta terhadap program PKH yang nantinya akan memberikan dampak yang logis bagi kehidupan mereka terutama pada peningkatan kualitas hidup melalui kesehatan dan pendidikan yang nantinya dapat memutus rantai kemiskinan.

Masih terjadi rendahnya sumber daya manusia di Kecamatan Buleleng mengakibatkan kualitas sumber daya manusia yang masih rendah dan rendahnya daya saing dalam merebut peluang kerja. Sehingga, hal itu menjadi penyebab tingginya angka pengangguran dan kemiskinan. Rendahnya sumberdaya manusia ini latarbelakangi oleh tingkat pendidikan yang masih rendah. Berdasarkan grafik pendidikan di Kecamatan Buleleng tahun 2014 dapat dilihat bahwa jumlah penduduk yang telah menempuh pendidikan Sekolah Dasar lebih banyak dibanding dengan penduduk yang telah menempuh Sekolah Menengah Pertama dan SMA/sederajat. Hal ini dijabarkan dengan perolehan nilai yaitu 17.263 jiwa yang telah lulus Sekolah Dasar, 7.183 tamatan SMP dan 11. 547 tamatan SMA sederajat (BPS,2014).

Berkaitan di bidang kesehatan, angka kematian bayi dan ibu cenderung mengalami fluktuasi, pada tahun 2011 berjumlah 71 orang, kemudian mengalami kenaikan di tahun 2012 sebanyak 89 orang, sedangkan tahun 2013 berjumlah 43 orang dan 2014 berjumlah 19 orang. Dilihat dari sisi masyarakat, cara hidup masyarakat masih kurang mementingkan gaya hidup bersih, sehingga mudah sekali terserang penyakit.

Sesuai dengan rumusan masalah di atas, maka tujuan penelitian ini adalah untuk mengetahui. Program IPM di Kecamatan Buleleng, Kabupaten Buleleng tahun 2011-2014. Pengentasan kemiskinan di Kecamatan Buleleng, Kabupaten Buleleng tahun 2011-2014. Pengaruh program IPM terhadap pengentasan kemiskinan di Kecamatan Buleleng, Kabupaten Buleleng tahun 2011-2014.

\section{METODE}

Jenis penelitian yang digunakan adalah penelitian kausalitatif, yaitu penelitian yang diarahkan untuk menyelidiki hubungan sebab akibat bersadarkan pengamatan terhadap akibat yang terjadi dan mencari faktor yang menjadi penyebab melalui data yang dikumpulkan (Zuriah,2005:57). Variabel yang dilibatkan adalah variabel bebas sebagai variabel yang mempengaruhi dan variabel terikat sebagai variabel yang dipengaruhi. Variabel bebas dalam penelitian ini adalah Program IPM (X) sedangkan yang termasuk dalam variabel terikat adalah upaya pengentasan kemiskinan (Y). Program IPM dalam penelitian ini adalah Program Keluarga Harapan (PKH).

Lokasi penelitian berada di Kecamatan Buleleng, Kabupaten Buleleng. Pemilihan lokasi ini dikarenakan lebih dari $11 \%$ penduduk miskin di Kabupaten Buleleng berada di Kecamatan Buleleng. Selain itu, masih terjadi permasalahan di bidanng pendidikan dan kesehatan.

Subjek dalam penelitian ini adalah masyarakat miskin (KK miskin kategori P1) atau Keluarga Sangat Miskin (KSM) yang mendapatkan dana bantuan PKH di Kecamatan Buleleng, Kabupaten Buleleng tahun 2011-2014 dan stakeholders dari PKH. Objek penelitian adalah program IPM dan pengentasan kemiskinan di Kecamatan Buleleng, Kabupaten Buleleng tahun 2011-2014.

Sumber data yang digunakan adalah data primer dan data sekunder. Data primer yang dikumpulkan adalah data kuantitatif berupa angka-angka yang diperoleh melalui kuisioner tentang program IPM dan pengentasan 
kemiskinan. Data sekunder berupa data kuantitatif dan data kualitatif. Data kuantitatif yaitu jumlah penduduk miskin di Kecamatan Buleleng menurut data PPLS Provinsi Bali tahun 2011, Data Penerima PKH tahun 2011-2014, data angka putus sekolah tahun 2011-2014, dan data kematian ibu dan bayi tahun 2011-2014. Data kualitatif mengenai hasil wawancara yang dilakukan kepada kepala atau pegawai dari instansi yang terkait dan KSM yang mendapat dana bantuan $\mathrm{PKH}$.

Teknik pengumpulan data dalam penelitian ini yaitu dokumentasi, wawancara dan kuisioner. Kusioner digunakan untuk mendapatkan data penelitian berupa persepsi bantuan, persepsi manfaat, partisipasi di bidang pendidikan dan kesehatan responden tentang program IPM, dan pengentasan kemiskinan diukur berdasarkan indikator BKKBN di Kecamatan Buleleng, Kabupaten Buleleng. Kuisioner ini diberikan kepada KSM yang mendapatkan dana bantuan PKH untuk memperoleh informasi mengenai program IPM yang mempengaruhi pengentasan kemiskinan di Kecamatan Buleleng, Kabupaten Buleleng. Untuk akuratan data yang diperoleh, maka teknik kuisioner dibantu dengan teknik interview quide atau wawancara langsung dengan responden mengingat tidak semua responden bisa menbaca dan menulis. Wawancara juga dilakukan kepada informan dari kepala instansi terkait. Sedangkan dokumentasi dilakukan dengan mengamati dokumen-dokumen atau catatan-catatan yang tersimpan di Kantor UPPKH (Unit Pelaksana Program Keluarga Harapan) Kabupaten Buleleng, Dinas Perencanaan dan Pembangunan Daerah Kabupaten Buleleng, Badan Pusat Statistik dan Dinas Sosial Kabupaten Buleleng.

Populasi dalam penelitian ini adalah jumlah KSM yang menjadi peserta PKH pada tahun 2014 yaitu sebanyak 515 orang responden. Teknik pengambilan sampel yang digunakan adalah teknik probability sampling, yaitu teknik pengambilan sampel dengan memberikan kesempatan yang sama bagi setiap unsur atau anggota populasi untuk dipilih menjadi sampel. Penentuan sampel dilakukan dengan teknik penyampelan acak wilayah berimbang atau proporsional stratified random sampling agar data yang diperoleh lebih representatif. Sampel dalam penelitian ini sebanyak 84 dengan menggunakan formulasi yang dikembangkan oleh Slavin.

Pengujian instrumen penelitian ini dilakukan di Kecamatan Buleleng yang tersebar di 24 desa/kelurahan penerima dana bantuan PKH tahun 2014, dengan mengambil sampel untuk pengujian intrumen sebanyak 30 orang responden diluar sampel yang diteliti. Pengujian intrumen ini yaitu uji validitas dan reliabilitas.

Menurut Murti dan Salamah (2006), validitas menunjukkan sejauh mana ketepatan, kesesuaian, atau kecocokan suatu alat untuk mengukur apa yang akan diukur. Uji validitas diperoleh dengan cara mengkorelasikan setiap skor dengan total skor indikator variabel, kemudian hasil korelasinya dibandingkan dengan nilai kritis pada signifikan 0,05 (Sugiyono, 2010:109). Syarat minimum instrumen penelitian dikatakan valid apabila nilai $r_{\text {hitung }}>r_{\text {tabel }}$. Uji validitas instrumen menggunakan teknis analisis korelasi product moment pearson dan menggunakan bantuan SPSS 17.0 for windows untuk memudahkan mengolah data penelitian.

Uji reliabilitas adalah pengujian instrumen penelitian yang digunakan untuk mengetahui tingkat ketepatan, ketelitian atau keakuratan yang ditunjukkan oleh instrumen pengukuran. Menurut Murti dan Salamah (2006), reliabilitas menunjukkan konsistensi atau kemantapan penggunaan alat ukur dalam penelitian, baik ditinjau dari waktu ke waktu maupun dari kondisi satu dengan kondisi yang lain. Uji reliabilitas dihitung dengan koefisien alpha cronbach menggunakan program SPSS 17.0 for Windows. Kriterianya, jika nilai alpha cronbach lebih besar dari 0,6 maka dinyatakan reliabel. 
Metode analisis data yang digunakan adalah analisis deksriptif kuantitatif dan analisis korelasi product moment. Analisis deskriptif kunatitatif digunakan untuk mengetahui program IPM dan pengentasan kemiskinan di Kecamatan Buleleng, Kabupaten Buleleng apakah berada pada kategori sangat baik, baik, cukup baik, kurang baik dan tidak baik maka akan dibuat pengklarifikasian yang mengacu pada ketentuan seperti yang dikemukakan oleh Irianto (2008:22).

Analisis korelasi product moment digunakan untuk mencari besarnya koefisien korelasi antara dua variabel (program IPM dengan pengentasan kemiskinan). Menurut Azhar, Irshad (2004:123), setelah diperoleh koefisien korelasi " $r$ " product moment maka dilakukan interprestasi secara sederhana yaitu dengan mencocokkan hasil penelitian dengan angka indeks korelasi " $r$ " product moment. Setelah ini, hasil penelitian dicocokkan dengan nilai koefisien korelasi " $\mathrm{r}$ " product moment baik pada taraf signifikasi $5 \%$ maupun pada taraf $1 \%$ kemudian dibuat kesimpulan apakah terdapat korelasi positif yang signifikan atau tidak.

\section{HASIL DAN PEMBAHASAN Hasil}

Program Indeks Pembangunan Manusia (IPM) pada penelitian ini adalah Program Keluarga Harapan (PKH). Pelaksanaan PKH di Kecamatan Buleleng, Kabupaten Buleleng sudah dilakukan sejak tahun 2010, berarti saat ini PKH sudah berjalan selama 5 tahun. Sejak awal program ini digulirkan pada masyarakat, mereka berharap bisa terbantu secara ekonomi. PKH merupakan satu-satunya program dari pemerintah pusat yang digulirkan untuk meningkatkan angka IPM melalui akses pendidikan dan akses kesehatan yang nantinya juga akan meningkatkan daya beli masyarakat.

Pada tahun 2011 jumlah Keluarga Sangat Miskin (KSM) yang menerima dana PKH sebanyak 563 dengan nilai RP 825.150.000,00. Pada awal bulan, tahun 2011 pendamping Kecamatan
Buleleng mendapat kunjungan monitoring dari Kementrian Komunikasi dan Informatika yang juga mempunyai kerjasama untuk program $\mathrm{PKH}$. Kemudian dilanjutkan dengan monitoring ke fasilitas kesehatan dan fasilitas pendidikan.

Pencairan dana setiap tahun dilaksanakan empat tahap, pada tahun 2011 ini pencairan tahap keempat dilaksanakan pada bulan Desember. Pencairan dana $\mathrm{PKH}$ dilaksanakan di kantor pos di daerah setempat dan pembayaran dilaksanakan juga verifikasi pendamping terhadap peserta $\mathrm{PKH}$. Permasalah yang terjadi mengenai dana $\mathrm{PKH}$ pada tahun 2011 adalah KSM yang tidak mencairkan dana sesuai jadwal, karena beberapa KSM yaitu yang menjadi buruh tani yang telah memiliki kelompok untuk memanen padi jika mereka tidak ikut pada saat itu otomatis akan dikeluarkan dari kelompok tersebut. sehingga pihak UPPKH Kecamatan Buleleng memberikan solusi dengan memberikan kesempatan pencairan dana pada hari selanjutnya.

Pada tahun 2012 jumlah KSM yang menerima bantuan $\mathrm{PKH}$ di Kecamatan Buleleng mengalami penurunan yakni hanya sebesar 553 KSM dengan jumlah nominal sebesar Rp 811.725.000,00. Kegiatan PKH pada tahun 2012 sama dengan tahun sebelumnya, seperti pertemuan kelompok untuk mengentahui keadaan $\mathrm{KSM}$, kegiatan rutin pertemuan dengan pendamping dan operator juga pendamping mengenai perubahan status dan evaluasi mengenai verifikasi yang telah dilakukan.

Permasalah yang muncul pada tahun 2012 yakni adanya KSM peserta $\mathrm{PKH}$ yang mengunakan kartu $\mathrm{PKH}$ untuk berobat tetapi ditolak oleh instansi terkait. Kejadian seperti ini memang sering kali terjadi, walaupun UPPKH Kecamatan Buleleng sudah bekerjasama dengan Dinas Kesehatan. Tindak lanjut atas permasalahan ini dalah pendamping harus menginformasikan ke KSM bahwa kartu PKH tidak dapat dipakai untuk berobat. 
Peserta PKH pada tahun 2013 mengalami penurunan sehingga jumlah KSM sebesar 532 KSM dengan dana sebesar Rp 944.465.000,00. Pelaksanaan $\mathrm{PKH}$ pada tahun ini dilaksanakan dengan kegiatan rutin seperti pertemuan kelompok, pendamping dan operator UPPKH Kecamatan Buleleng dan pencairan dana PKH. Selain itu, pada tahun 2013 ini pendamping menyerahkan bibit babi bagi KSM yang berprestasi untuk membantu perekonomian KSM. Pendamping Kecamatan Buleleng juga mengikuti mengikuti kegiatan pemantapan pendamping dan operator di Jakarta selama 4 hari dan merupakan wakil dari Provinsi Bali. UPPKH Kabupaten Buleleng mendapat juara ke II pada Lomba Video. Di akhir tahun diisi dengan koordinasi ke PT ASKES untuk mengetahui prosedur BPJS kesehatan yang akan mulai diberlakukan pada tahun 2014.

Penerima dana PKH tahun 2014 berjumlah $515 \mathrm{KSM}$. Program PKH pada tahun 2014 ini diawali dengan koordinasi dengan pihak BPJS juga berkoordinasi dengan pihak Dinas Kesehatan mengenai JKBM (jaminan kesehatan daerah untuk seluruh masyarakat di Bali), pada koordinasi ini pendamping menanyakan mengenai kartu JKBM karena ada KSM yang tidak memiliki kartu, dalam hal ini peserta $\mathrm{PKH}$ yang tidak memiliki kartu JKBM atau Jamkesmas dapat gratis berobat dengan syarat harus memilki KTP Bali dan Kartu Keluarga. Pelaksanaan Program Indeks Pembangunan Manusia (IPM) di Kecamatan Buleleng, Kabupaten Buleleng tahun 2011-2014 dapat dilihat pada Tabel 1 sebagai berikut.

Tabel 1. Hasil rogram IPM di Kecamatan Buleleng, Kabupaten Buleleng tahun 2011-2014

\begin{tabular}{llcc}
\hline No & \multicolumn{1}{c}{ Dimensi/Variabel } & Skor & Kategori \\
\hline 1 & Program IPM & 4.722 & Sangat Baik \\
2 & Persepsi Bantuan & 886 & Baik \\
3 & Persepsi Manfaat & 640 & Baik \\
4 & Partisipasi dalam Bid. Kesehatan & 1.459 & Sangat Baik \\
5 & Partisipasi dalam Bid. Pendidikan & 1.737 & Baik \\
\hline
\end{tabular}

Berdasarkan Tabel 1, program IPM secara keseluruhan berada pada skor 4.722, nilai tersebut berada pada rentang skor 4.700-5.580. rentang skor program IPM berada pada kategori sangat baik. Dari hasil tersebut menandakan bahwa Program IPM di kecamatan Buleleng, Kabupaten Buleleng tahun 2011-2014 berjalan dengan sangat baik.

Dari hasil penskoran yang dilakukan, diperoleh hasil bahwa skor total Program IPM di Kecamatan Buleleng, Kabupaten Buleleng tahun 2011-2014 berada pada kriteria sangat baik pada skor 4.772. Hasil tersebut menunjukkan bahwa Program IPM terhadap pengentasan kemiskinan dapat dikatakan sangat baik. Dilihat dari masing-masing dimensi pun terlihat hasil yang baik, mulai dari dimensi persepsi bantuan yang berada pada kategori baik pada skor 886, dimensi persepsi manfaat yang berada di kategori baik pada skor 640, partisipasi dalam bidang kesehatan berada pada kategori sangat baik pada skor 1.459 dan dimensi partisipasi dalam bidang pendidikan berada pada kategori baik dengan skor 1.737. Program IPM perlu dipertahankan agar tetap berada pada kategori sangat baik.

Tingkat kemiskinan yang terdapat di Kacematan Buleleng, Kabupaten Buleleng selama empat tahun terakhir digambarkan dengan menggunakan data PPLS Provinsi Bali tahun 2011. Dalam data PPLS tersebut, angka kemiskinan di Kecamatan Buleleng yang terdiri dari 27 desa/kelurahan kategori kelompok 1 berjumlah $635 \mathrm{KK}$. Kategori kelompok II berjumlah 2.168 $\mathrm{KK}$ dan kategori III berjumlah $2.625 \mathrm{KK}$. Dengan demikian total keselurahn angka kemiskinan di Kecamatan Buleleng berjumlah $5.428 \mathrm{KK}$ dan 
menyumbang $11 \%$ lebih penduduk miskin di Kabupaten Buleleng.

$$
\text { Melihat besarnya angka }
$$

kemiskinan yang ada di Kecamatan

Buleleng maka pemerintah melakukan berbagai upaya dalam mengentaskan kemiskinan yang terjadi. Secara umum program pengentasan kemiskinan yang dilakukan oleh pemerintah memiliki dua tujuan yaitu mengurangi pengeluaran masyarakat miskin, yang dibebankan kepada pihak lain seperti ke pemerintah atau masyarakat lainnya dan meningkatkan pendapatan penduduk miskin sehingga dapat keluar dari jurang kemiskinan.

Pengentasan kemiskinan di
Kecamatan Buleleng, Kabupaten
Buleleng tahun $2011-2014$
menggunakan sembilan dimensi yaitu
pendapatan dan kepemilikan asset,
pemenuhan kebutuhan spiritual,
pemenuhan kebutuhan pangan,
pemenuhan kebutuhan pakaian,
pendidikan anak, perawatan kesehatan
keluarga, informasi, rekreasi dan
aktualisasi diri. Hasil skoring mengenai
upaya pengentasan kemiskinan di
Kecamatan Buleleng Kabupaten
Buleleng tahun 2011-2014 baik secara
keseluruhan maupun perdimensi akan
disajikan pada Tabel2.

\section{Tabel 2. Hasil Pengentasan Kemiskinan pada Kecamatan Buleleng, Kabupaten Buleleng} Tahun 2011-2014

\begin{tabular}{llcc}
\hline No & \multicolumn{1}{c}{ Dimensi/Variabel } & Skor & Kategori \\
\hline 1 & Upaya Pengentasan Kemiskinan & 4.425 & Baik \\
2 & Pendapatan dan Kepemilikan Aset & 188 & Kurang Baik \\
3 & Pemenuhan Kebutuhan Spiritual & 389 & Sangat Baik \\
4 & Pemenuhan Kebutuhan Pangan & 773 & Sangat Baik \\
5 & Pemenuhan Kebutuhan Pakaian & 641 & Baik \\
6 & Pendidikan Anak & 287 & Baik \\
7 & Perawatan Kesehatan Keluarga & 663 & Baik \\
8 & Informasi & 730 & Sangat Baik \\
9 & Rekreasi & 516 & Cukup Baik \\
10 & Aktualisasi Diri & 241 & Cukup Baik \\
\hline
\end{tabular}

Berdasarkan Tabel 2, pengentasan kemiskinan di Kecamatan Buleleng, Kabupaten Buleleng tahun 2011-2014 secara keseluruhan berada pada skor 4.425 dan berada pada rentang skor 3.819-4.700 dengan kategori baik. Dari hasil tersebut menadakan bahwa pengentasan kemiskinan di Kecamatan Buleleng, Kabupaten Buleleng tahun 2011-2014 berjalan dengan baik.

Dilihat dari masing-masing dimensi pun terlihat hasil yang baik, mulai dari pendapatan dan kepemilikan asset yang berada di kategori kurang baik pada skor 188, pemenuhan kebutuhan spiritual yang sangat baik pada skor 389, pemenuhan kebutuhan pangan berada di kategori sangat baik pada skor 773, pemenuhan kebutuhan pakaian pada kategori baik dengan skor 641 , pendidikan anak kategori baik dengan skor 287, perawatan kesehatan keluarga kategori baik dengan skor 663 , informasi berada pada kategori sangat baik dengan skor 730, rekreasi pada kategori cukup baik dengan skor 516 dan aktualisasi diri pada kategori cukup baik dengan skor 241. Berdasarkan temuan ini menunjukkan bahwa secara total berada pada kategori baik. Hal ini mengidentifikasikan bahwa pengentasan kemiskinan di Kecamatan Buleleng, Kabupaten Buleleng tahun 2011-2014 masih perlu ditingkatkan.

Pemerintah pusat, pemerintah daerah dan segala instansi terkait masih perlu meningkatkan upaya pengentasan kemiskinan yang masih dalam kategori baik, agar dapat mencapai kategori sangat baik di waktu yang akan datang. Hal tersebut dapat dilakukan dengan cara lebih mengoptimalkan segala program pengentasan kemiskinan, tidak hanya ditekankan pada pengentasan 
kemiskinan secara sektoral namun lebih mengena pada masyarakat itu sendiri. Kinerja dari masing-masing instansi dan koordinasi sangat diperlukan dan harus lebih ditingkatkan. $\begin{array}{ccc}\text { Besar korelasi product moment } & \text { mograp } \\ \text { program IPM terhadap upaya }\end{array}$ pengentasan kemiskinan di Kecamatan Buleleng, Kabupaten Buleleng tahun 2011-2014 dapat dilihat pada Tabel 3.

Tabel 3. Hasil Korelasi $X$ dan $Y$ dengan Program SPSS 17.0 FW

\begin{tabular}{lcccc}
\hline Model & $\mathrm{R}$ & $\mathrm{R}$ Square & Adjusted R Square & $\begin{array}{c}\text { Std. Error of the } \\
\text { Estimate }\end{array}$ \\
\hline 1 & $.594^{\mathrm{a}}$ & .352 & .344 & 3.546708 \\
\hline
\end{tabular}

Berdasarkan Tabel 3 dapat dilihat bahwa nilai "r" hitung sebesar 0,594. Dengan nilai df sebesar 82 ( $\mathrm{Df}=\mathrm{N}-\mathrm{nr}$ ) diperoleh nilai $r_{\text {tabel }}$ pada taraf $5 \%$ signifikan sebesar 0,2146. Ternyata nilai $r_{x y}$ sebesar $0,594>r_{\text {tabel }}$ sebesar 0,2146 , karena nilai $r_{x y}$ lebih besar dari

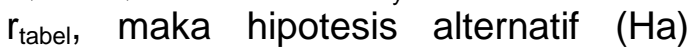
diterima dan hipotesis nihil (Ho) ditolak.
Hal ini berarti terdapat korelasi/pengaruh positif yang signifikan antara variabel $X$ (Program IPM) dan $Y$ (Pengentasan Kemiskinan). Sedangkan untuk perhitungan pengaruh program IPM terhadap pengentasan kemiskinan di Kecamatan Buleleng, kabupaten Buleleng dapat dilihat pada Tabel 4.

Tabel 4. Hasil Perhitungan Pengaruh Program IPM Terhadap Pengentasan Kemiskinan di Kecamatan Buleleng

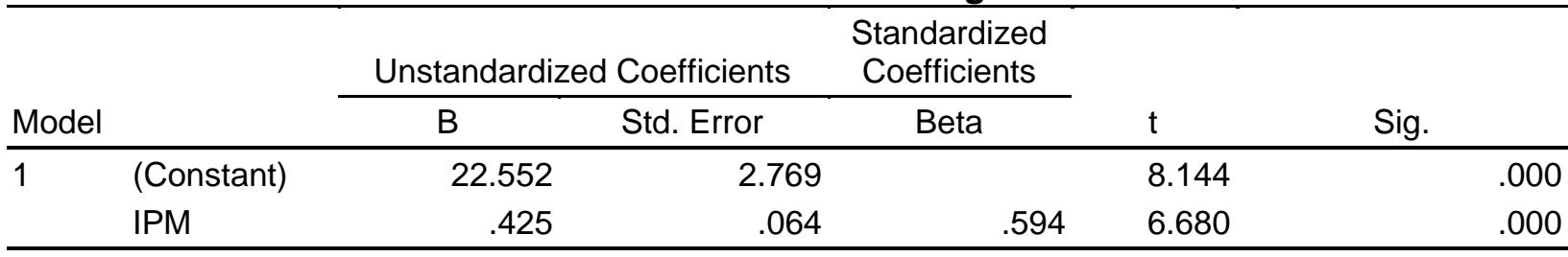

Hasil analisis pada Tabel 4 menunjukkan bahwa nilai $t_{\text {hitung }}=6,680$ $>t_{\text {tabel }}=1,671$ atau $p$-value $=0,000<\alpha$ $=0,05$. Hasil ini dapat disimpulkan bahwa $\mathrm{Ha}$ diterima dan $\mathrm{HO}$ ditolak, sehingga dengan demikian terdapat pengaruh yang positif dan signifikan program IPM terhadap pengentasan kemiskinan di Kecamatan Buleleng, Kabupaten Buleleng Tahun 2011-2014. Besarnya pengaruh program IPM terhadap pengentasan kemiskinan digunakan analisis koefisien determinasi $\left(R^{2}\right)$ yang dapat dilihat pada Tabel 3.

Berdasarkan hasil analisis pada Tabel 3 menunjukkan besarnya sumbangan pengaruh variabel program IPM (X) terhadap pengentasan kemiskinan $(Y)$ adalah sebesar 0,352. Hal ini berarti pengentasan kemiskinan di Kecamatan Buleleng, Kabupaten
Buleleng $35,2 \%$ dipengaruhi oleh Program IPM. Sedangkan sisanya $0,648(64,8 \%)$ dipengaruhi oleh faktor lain yang tidak diungkapkan dalam penelitian ini.

\section{Pembahasan}

Berdasarkan hasil penelitian mengenai pengaruh program IPM terhadap pengentasan kemiskinan di Kecamatan Buleleng, Kabupaten Buleleng tahun 2011-2014, dapat diketahui bahwa program IPM mempengaruhi pengentasan kemiskinan di Kecamatan Buleleng, Kabupaten Buleleng. Hasil penelitian ini sejalan dengan penelitian Cladio Usman (2013), mengatakan bahwa terdapat hubungan yang positif dan signifikan antara Program Keluarga Harapan (Program IPM) terhadap pengentasan kemiskinan. Selain itu, 
didukung juga oleh penelitian dari Fakkhul Mufid Cholili (2014), yang menyatakan bahwa IPM berpengaruh negatif terhadap jumlah penduduk miskin yang ada di 33 provinsi di Indonesia.

Pengentasan kemiskinan di Kecamatan Buleleng, Kabupaten Buleleng tahun 2011-2014 berada pada kategori baik. Dalam hal ini Kecamatan Buleleng masih perlu meningkatkan pengentasan kemiskinan misalnya dengan cara pengentasan secara sektoral, masyarakat pun jangan dibiasakan untuk berada di zona nyaman, harus ada program yang memang benar-benar menyentuh masyarakat langsung dan bersifat jangka panjang.

Berdasarkan hasil pengolahan data diperoleh koefisien korelasi sebesar 0,594 hal ini menunjukkan keeratan hubungan antara program IPM terhadap pengentasan kemiskinan. Menurut Azhar, Irshad (2003:123) bila angka tersebut diklasifikasikan berada diantara 0,40-0,59 berarti antara variabel $X$ (program IPM) dan variabel $Y$ (pengentasan kemiskinan) terdapat korelasi yang sedang. Sedangkan dari hasil penelitian yang diperoleh dapat dibuktikan bahwa program IPM berpengaruh positif dan signifikan terhadap pengentasan kemiskinan di Kecamatan Buleleng, Kabupaten Buleleng tahun 2011-2014 dapat dilihat dari nilai $t_{\text {hitung }}=6,680>t_{\text {tabel }}=1,671$ atau $p$-value $=0,000<\alpha=0,05$. Hasil ini dapat disimpulkan bahwa $\mathrm{Ha}$ diterima dan HO ditolak, sehingga dengan demikian terdapat pengaruh yang positif dan signifikan program IPM terhadap pengentasan kemiskinan di Kecamatan Buleleng, Kabupaten Buleleng Tahun 2011-2014.

Dari hasil analisis yang dilakukan, diketahui bahwa besarnya koefisien determinasi $\left(R^{2}\right)$ adalah sebesar 0,352. Dari hasil ini menunjukkan bahwa besarnya sumbangan pengaruh program IPM terhadap pengentasan kemiskinan di Kecamatan Buleleng, Kabupaten Buleleng tahun 2011-2014 adalah sebesar $35,2 \%$ dan sisanya $64,8 \%$ dipengaruhi oleh faktor lain.

\section{SIMPULAN DAN SARAN Simpulan}

Berdasarkan hasil analisis data yang telah dilakukan, maka dapat ditarik kesimpulan program Indeks Pembangunan Manusia (IPM) di Kecamatan Buleleng, Kabupaten Buleleng baik secara total maupun per dimensi berada pada kategori sangat baik dengan skor 4.722 dengan rentang skor $4.700-5.580$. Hal ini memberikan indikasi bahwa program IPM perlu dipertahankan lagi agar tetap dalam kategori sangat baik.

Pengentasan kemiskinan di Kecamatan Buleleng, Kabupaten Buleleng secara total maupun per dimensi berada dalam kategori baik dengan skor 4.425 dengan rentang skor 3.819 - 4.700. Hal ini memberikan indikasi bahwa pengentasan kemiskinan perlu lebih ditingkatkan lagi agar mencapai kategori sangat baik. Program IPM berpengaruh positif dan signifikan terhadap pengentasan kemiskinan di Kecamatan Buleleng, Kabupaten Buleleng. Hal ini ditunjukkan dengan nilai $t_{\text {hitung }}=6,680>t_{\text {tabel }}=1,671$ atau $p$-value $=0,000<\alpha=0,05$ dengan besar korelasi sebesar 0,594. Besarnya pengaruh program IPM terhadap pengentasan kemiskinan adalah 35,2\% dilihat dari koefisien determinasi $\left(R^{2}\right)$. Hal ini berarti program IPM berperan penting dalam upaya mendukung pengentasan kemiskinan.

\section{Saran}

Berdasarkan simpulan diatas, maka dapat dikemukakan beberapa saran. Bagi Dinas Sosial, UPPKH Program Keluarga Harapan tingkat Kecamatan Buleleng agar program IPM lebih dimaksimalkan terutama antara pendamping dan peserta. Badan Pusat Statistik dan Badan Perencanaan Pembangunan Daerah Kabupaten Buleleng agar menyediakan data sampai di tingkat kecamatan. Bagi masyarakat penerima bantuan $\mathrm{PKH}$, agar tidak menjadi pasif dan masih 
terbelenggu lingkaran kemiskinan dan memanjakan diri berada di zona aman, serta bagi peneliti selanjutnya diharapkan dapat mengembangkan penelitian selanjutnya dengan topik yang sama tetapi mempertimbangkan variabel lain yang dapat mempengaruhi upaya pengentasan kemiskinan.

\section{DAFTAR PUSTAKA}

Arikunto, Suharsimi. 2012. Prosedur Penelitian Suatu Pendekatan Praktik. Rineka Cipta, Jakarta.

Arsyad, Lincolin. 2004. Ekonomi Pembangunan. Yogyakarta:STIE Yayasan Keluarga Pahlawan Negara.

Badan Perencanaan Pembangunan Daerah. 2013. Analisis IPM kabupaten Buleleng 2008-2012. Singaraja:Bappeda.

------. 2011. Data PPLS Kabupaten Buleleng.Singaraja:Bappeda

Badan Pusat Statistik. 2012. Profil Kemiskinan Provinsi Bali. Denpasar:BPS.

Badan Pusat Statistik. 2014. Data dan Informasi Kemiskinan Kabupaten Buleleng 2004-2014. Singaraja:BPS

------. 2014. Buleleng dalam Angka 2014. Singaraja:BPS.

Badrudin, Rudy. 2012. Ekonomika Otonomi Daerah. Yogyakarta:UPP STM YKPN.

Dantes, Nyoman. 2012. Metode Penelitian. Yogyakarta:Andi Offset.

Darwin, Muhadjir. 2010. "Tinjauan Implementasi Strategi Nasional Penanggulangan Kemiskinan" dalam Tukiran, Agus Joko Pitoyo, dan Pande Made Kutanegara (eds.), Akses Penduduk Miskin terhadap Kebutuhan Dasar.
Yogyakarta: Pusat Studi Kependudukan dan Kebijakan Universitas Gadjah Mada hlm 3972.

Dinas Sosial. 2014. Buku Saku Program Keluarga Harapan (PKH). Denpasar:Dinas Sosial.

Hasan, lqbal. 2012. Pokok-pokok Materi Statistik 2. Jakarta:PT Bumi Aksara.

Irianto, Agus. 2004. Statistik Konsep Dasar dan Aplikasinya. Jakarta:prenada Media.

Kuncoro, Mudrajad. 2005. Ekonomi Pembangunan Teori, Masalah dan Kebijakan. Yogyakarta:UPP AMP YKPN.

Lubis, Irsyad dkk. Pembangunan Manusia dan Faktor-faktor yang mempengaruhinya. 2008. Wahana Hijau: Jurnal Perencanaan dan Pengembangan Ekonomi Wilayah Vol. 4 No.1.

Mankiw, Gregory. 2006. Pengantar Ekonomi Edisi Kedua. Jakarta:Erlangga.

Mulyaningsih, Yuni. 2008. Pengaruh Pengeluaran Pemerintah Di Sektor Publik Terhadap Peningkatan Pembangunan Manusia Dan Pengurangan Kemiskinan. Laporan Penelitian:IPB.

Nainggolan, Togiaratua,dkk. 2012. Program Keluarga Harapan Indonesia, Dampak pada Tujuh Provinsi. Jakarta: P3KS Press.

Purwanto, Slamet Agus, Dkk. 2013. Implementasi Kebijakan Program Keluarga Harapan (PKH) dalam Memutus Rantai Kemiskinan (Kajian di Kecamatan Mojosari Kabupaten Mojokerto) WacanaVol. 16, No. 2. Semarang:Universitas Brawijaya. 
Rosyidi, Suherman. 2012. Pengantar Teori Ekonomi. Jakarta:PT Raja Grafindo Persada.

Setiadi, Teguh. 2013. Pengaruh Program Keluarga Harapan terhadap Peserta Program di Kelurahan Kertasari Kecamatan Ciamis Kabupaten Ciamis tahun 2012. Semarang:UNDIP.

Sukmanegara, Prima. 2011. Analisis Pengaruh IPM, PDRB per kapita, Jumlah Pengangguran terhadap Jumlah Penduduk Miskin di Provinsi Jawa Tengah. Semarang:UNDIP.

Subandi. 2012. Ekonomi Pembangunan. Bandung:Alfabeta.

Sudibia, I Ketut, A.A.I. Ngurah Marheni. 2014. Beberapa Strategi Pengentasan Kemiskinan di Kabupaten Karangasem, Provinsi Bali Piramida Vol. IX No. 1:1-14. Denpasar:Pusat Penelitian Kependudukan dan Pengembangan SDMUniversitas Udayana.

Sugiyono. 2010. Metode Penelitian Kuantitatif Kualitatif dan $R$ \& $D$. Bandung: Alfabeta.

Sukardi. 2007. Metodologi Penelitian Pendidikan Kompetensi dan Pratiknya.Jakarta:PT Bumi Aksara.
Sukirno, Sadono. 2000. Pengantar Teori Makro Ekonomi. Jakarta:PT Grafindo Persada.

------. 2004. Pengantar Teori Makro Ekonomi. Jakarta:PT Grafindo Persada.

Tjokrowinato, Moeljarto. 2004. Pembangunan, Dilema dan Tantangan. Yogyakarta:Pustaka Pelajar.

Todoro, Michael P dan Stephen C. Smith. 2009. Pembangunan Ekonomi Edisi Kesembilan. Jakarta:Earlangga.

2006. Pembangunan Ekonomi Dunia Ketiga. Jakarta:Earlangga.

Umar, Husein. 2005. Metode Penelitian untuk Skripsi dan Metode Bisnis. Jakarta:PT Raja Grafindo Indonesia.

Universitas Pendidikan Ganesha. 2013. Pedoman Penulisan Skripsi Dan Tugas Akhir Program Sarjana Dan Diploma 3 Universitas Pendidikan Gensha. Singaraja:Undiksha.

Zuriah, Nurul. 2006. Metodologi Penelitian Sosial Dan Pendidikan Teori-Aplikasi. Jakarta:Bumi Aksara. 